\title{
THE REALITY OF LEARNING AND CAPACITY-BASED FULFILLMENT AT DARUL MA'ARIF ISLAMIC BOARDING SCHOOL IN JAYAPURA
}

\author{
M. Syukri Nawir ${ }^{1}$ \\ Bahaking Rama ${ }^{2}$ \\ Muljono Damopolii ${ }^{3}$ \\ Munir $^{4}$ \\ IAIN Fattahul Muluk Papua, Indonesia ${ }^{1}$ \\ Lecture at The Faculty of Tarbiyah and Teacher Training Alauddin State Islamic \\ University Makassar ${ }^{2,3,4}$ \\ syukri.nawir1976@gmail.com¹, bahaking.rama@yahoo.co.id ${ }^{2}$, muldafat@gmail.com³ \\ muniralimuddin@gmail.com ${ }^{4}$
}

\begin{abstract}
This paper will elaborate deeply on the reality of learning and capacity-based fulfillment at Darul Ma'arif Islamic Boarding School in Jayapura. Qualitative descriptive research type, conducted on primary and secondary data sources with a phenomenological approach from a methodological perspective, educational sociology, and educational psychology from a scientific perspective using interview guidelines, observation sheets, and documentation tools as instruments to collect data that are processed and analyzed using reduction techniques. Data, data presentation, and data conclusions, and validity are tested by triangulation techniques and observation extension. The results showed that learning is carried out classically using formal standard methods, in addition to takhassus learning that studies classical Islamic books that bring results to the ability to memorize the Koran, mastering Arabic and English, and mastery of reading books in limited quantities. The fulfillment of capacity at the DarulMa'arif Islamic Boarding School in Jayapura is illustrated, that the aspects of the Kiai were not found in the three boarding schools, students from simple family backgrounds, education facilities, and infrastructure built from natural materials with semi-permanent capacity. Limited and the same curriculum refers to the Ministry of Religion.
\end{abstract}

\section{Keywords: Capacity Based Learning; Darul Ma'arif Numbay Islamic Boarding School}

\section{INTRODUCTION}

Boarding school is an educational institution of Islam for sustainable growth and development in society. Community development. This requires the development of learners who carried among others; attitude knowledge, intelligence, skills, and ability to communicate and interact with the public at large, as well as raise awareness of the natural environment, the principles of coaching like this is dita war right by the boarding school as the oldest Islamic institution in Indonesia.

The role of pesantren has long been recognized by the community and it is possible to be maximally involved in building this nation. Through the pesantren, the students or students learn religious and social sciences that are needed by society. Even 


\section{The Reality of Learning and Capacity-Based Fulfillment at Darul Ma'arif Islamic Boarding School in Jayapura}

so, pesantren become educational cadre institutions for santri or students who are ready to enter the community.

The birth of the pesantren cannot be separated from the Islamization process in Indonesia. The guardians, religious scholars, syekh, tengku, who accuse Islam usually have such educational institution in Java known as pesantren, in West Sumatra called the mosque, was in Aceh called menasah, rangkang or dayah. Even though it has a different name, it is essentially the same, namely an institution to study and deepen Islamic teachings. ${ }^{1}$

Islamic boarding schools in Indonesia have a long history. In the history of Islam in Indonesia, ulama played a very large role in establishing Islamic boarding schools and succeeded in Islamizing the archipelago extensively, especially in the XVII and XVIII centuries. ${ }^{2}$ Technically, pesantren is a place for students to live and study. This place refers to the main characteristics of schools, namely education as a whole in the sense intact. Pesantren is where students or pupils learn the Koran or also called pound dock (Language Center of the Ministry of Education, 2007) Pesantren comes from the word "penyantrian" meaning the process of educating a child to be students. Santri is a term that refers to the stat us and quality of a child who in his words and deeds is obedient and obedient to religious teachings. ${ }^{3}$

Islamic boarding schools or Islamic boarding schools are institutions which can be said to be a form of the natural process of developing the national education system. From the historical point of view, schools not only synonymous with the meaning of - Islamization but also imply authenticity Indonesia (indigenous). For a similar institution pesantren, it has existed since the reign of Hindu-Buddhist. Islam lives and converts existing educational institutions. Of course, this does not mean downplaying the role of Islam in pioneering education in Indonesia. ${ }^{4}$

Education in Islamic boarding schools plays a major role in character building in Indonesia. Boarding school had been tested as an institution that helped shape the character and personality of the citizens of the nation. Pesantren is a subculture of Islam rooted in Islamic culture in Indonesia. Education in schools not only has the means and educational practices but also arbitrary values or norms. Value is the result of a dynamic between religious values rooted in the text being taught, such as "Kitab Kuning" and the robustness of the principle of the caregivers/Kiai. Furthermore, this value communicates with socio-cultural and political realities that grow in the Indonesian culture and the external world (global) throughout history. ${ }^{5}$

Pesantren as a community and as a great educational institution and widely spread in different corners of the country has a lot of me given stock in the religious formation of the Indonesian people. This institution has given birth too many national

\footnotetext{
${ }^{1}$ Haedar Putra Daulay, Pendidikan Islam Dalam Sistem Pendidikan Nasional Di Indonesia (Jakarta: Premanadamedia Group, 2014).

${ }^{2}$ Azyumardi Azra, Jaringan Ulama Timur Tengah Dan Kepulauan Nusantara Abad XVII \& XVIII (Jakarta: Kencana Predana Media Group, 2004).

${ }^{3}$ Saiful Akhyar Lubis, Konseling Islam Kyai Dan Pesantren (Yogyakarta: Elsaq Presss, 2007)

${ }^{4}$ Nurcholish Madjid, Bilik-Bilik Pesantren (Jakarta: Dian Rakyat, 2010).

${ }^{5}$ Idham, Potret Pemberdayaan Santri; Pesantren Dan Studi Islam (Jakarta: Panrita Global Media, 2010).
} 
leaders in the past, present, and presumably also in the future. Graduates of the schools many of which take active participation in the creation of building the nation. ${ }^{6}$

Pesantren continues to develop while facing obstacle after obstacle. This attitude is not offensive but interpreted as defensive because it is to save his life and the continuity of Islamic preaching. Pesantren never start a confrontation, because first the launch propaganda and plant right education. In step follows boarding accepted by society as an effort to educate, increase peace, and help socio-psikis, for them. Not men $g$ was surprised by if schools then become the pride for goodness surrounding mainly Muslim. ${ }^{7}$

Education and society are two variables that are difficult to separate. The relationship between the two (education and society) is realistic. How to ensure that education is not only carried away by the dynamics of change but it can portray itself as an agent of change itself.

Adolphe E Meyer as quoted by Imam Barnadib. ${ }^{8}$ states that:

"Between education and society reflect each other. The relationship between the two is not linear, but rather a reciprocal relationship (symbiotic mutual). Figerlind refer to the relationship between the dialectic."

When that happens, society changes will bring changes to the early vice. Changes in education will bring materials to societies. According to Imam Barnadib, in theory, for goodness society has changed from traditional to modern society.

Simplistically, society will move from an agrarian society to an industrial society than an information society. Three typologies for goodness rakat such a simplistic manner has a culture and values that are different from one another.

Agricultural society is a traditional society. The culture that stands out the most is "gotong royong". Industrial society has values and culture as delayed pleasure, work planning the future, subject to the rules of bureaucratic supervision lot more done than instruction, routine, instrumental attitude to work, hard work productively rated as good. Whereas in the information society, society is already so complex, the country is already happening transparently so that the world already global society. ${ }^{9}$

The problem that arises is how education, including messages trends, will prepare outputs it in the face of changes in society that continue to drive so that they can deal with the changes that occur in the community, can play a role coloring and can be accommodated in all sectors of the community. Furthermore, the output of the pesantren can be an agent of change itself. This is a big question that requires immediate answers by pesantren.

Judging from the spectrum of nation-building, there is no denying that boarding schools in addition to being an educational institution of Islam, as well as a part of community infrastructure in socio-cultural participate actively in the process of forming public awareness to have ideals for the betterment of his country.

Islamic boarding school learning activities have their characteristics to achieve efficient and effective learning objectives, so that in its development the output of the

\footnotetext{
${ }^{6}$ Ahmad Tafsir, Ilmu Pendidikan Islam (Bandung: Remaja Rosda Karya, 2013).

${ }^{7}$ Mujammil Qomar, Pesantren Dari Transformasi Metodologi Menuju Demokratisasi Institusi (Jakarta: Erlangga, 2002).

${ }^{8}$ Imam Barnadib, Ke Arah Perspektif Baru Pendidikan (Yogyakarta: FIP-IKIP, 1994).

${ }^{9}$ Barnadib.
} 
pesantren can have a positive impact on various parties, both student educational institutions, and the community as the word of Allah swt., in QS al-Qasas/28: 77.

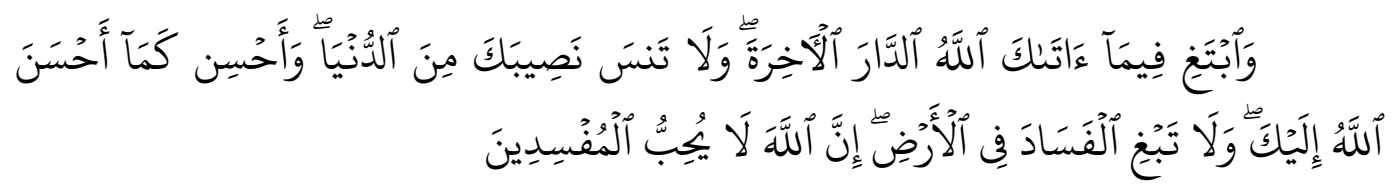

Translation:

"And look for what Allah has given you (happiness) in the hereafter, and do not forget your happiness from worldly (enjoyment)."

The process of searching for knowledge does not stop after the knowledge gained, but rather to look for efforts to put it into practice, harnessing him for the sake of happiness, fulfillment, and welfare of human life in this world and hereafter. Because Allah does not teach only the happiness of the hereafter, but the efforts made include the benefit of humans in the world.

Pesantren fostering the student form or create a human being capable in all aspects of faith and piety, not despite the elements are mutually reinforcing schools so that Islamic education can in maximized.

Mastuhu in Muljono Damopolii reveals in a more abstract and detailed manner the elements of the boarding school which he classified into three things: (1) the actors: Kiai, ustad, students, and administrators; (2) Hardware facilities: mosque, house of Kiai, cottage. Buildings for purposes such as libraries, halls, pesantren offices, offices of student organizations, security, cooperatives, workshops, sewing, and other skills; and (3) software objectives, curriculum, learning resources, namely books, books, and other learning resources, teaching and learning methods (bandongan, sorogan, halaqah, and memorization ) and teaching and learning evaluation. ${ }^{10}$ Here that is the object of research by revealing the capacity of boarding among others the capacity of actors, means of hardware, and software means.

Pesantren have different elements, depending on the level of large, small, and run educational trending program. There is a message the trend of small element simply by clerics, dorm/cottage, classic books, and teaching methods, while large schools, need to be supplemented with elements of the other, like the clerics as an auxiliary clerics in teaching, building schools or madrasah, the board, management, organization, accordance with the boarding.

Papua as a province located at the eastern tip of Indonesia is also inseparable from efforts to make changes in various fields to make it even better, including in the field of religious education, whether Christianity, Islam, Hinduism or Buddhism. Construction of boarding schools, both traditional and modern, in Jayapura can be said to be phenomenal because there are already more than 6 (six) boarding school in this city, but have not been able is expected, which can contribute to the development of Islamic education in Papua.

Realities that exist at this time, based on the results of preliminary observations, from some boarding schools scattered in Jayapura, schools still have various drawbacks of whom lack the means and pre facilities, the quality of

\footnotetext{
${ }^{10}$ Muljono Damopolii, Pesantren IMMIM Pencetak Muslim Modern (Jakarta: Rajawali Pers, 2011).
} 
teachers, to the quality of the material being taught, and still many disadvantages that the world development effort early Islam-based cottage in Jayapura.

Among the boarding school in the city of Papua is Darul Ma'arif located in Abepura Jayapura, was among the majority population were Muslim, standing since 2001. Pesantren have a program of formal education, namely; Early Childhood Education (PAUD), Madrasah Ibtidaiyyah (MI), and Madrasah Aliyah (MA).

The above-mentioned pesantren are privately owned or foundations. This pesantren applies a modern Pondok system with a mixed pattern between the traditional book recitation system and the madrasah system. Some schools provide education-based formal public schools. On the one hand, the number of students is relatively small, with the number of students being less than 1000 (one thousand). One reason is the territory of the reach and influence of limited boarding all districts alone.

Problematic boarding is the object of the study authors do not what is conveyed by Ramayulis, among them regarding: (1) The quality of teachers is not adequate, (2) Limited human resources and funds, (3) Productivity inst itution that was inferior, (4) The efficiency of education is low, (5) The relevance of education to the world of work, (6) Management of early pension uniform, (7) The learning process is rigid, (8) Facilities and infrastructure are not yet complete, (9) Libraries inadequate, and (10) Quality of input and output low. All the above issues still to be found so that it can be said the majority of Islamic education institutions, which seek non-Islamic education institutions (Christians) are not qualified. ${ }^{11}$

This paper will elaborate in-depth on the reality of capacitybased learning and fulfillment at the Darul Ma'arif Islamic Boarding School in Papua.

\section{RESEARCH METHODOLOGY}

This type of qualitative descriptive research was conducted on primary and secondary data sources with a phenomenological approach from a methodological perspective, sociology of education, and educational psychology from a scientific perspective using interview guidelines, observation sheets, and documentation tools as instruments for collecting data processed and analyzed using reduction techniques. Data, data presentation, and data conclusion, and its validity was tested by triangulation techniques and observation extension.

\section{III.RESULT AND DISCUSSION}

\section{A. The Reality of Capacity-Based Learning at Darul Ma'arif Islamic Boarding School}

Every activity, whatever its form, really requires realization, so that it can measure the achievement of activity, wherefrom the realization it can be estimated whether an activity goal can be achieved according to plan or not. Likewise with the capacity-based learning of Islamic boarding schools, where to be able to measure the

\footnotetext{
${ }^{11}$ Ramayulis, Ilmu Pendidikan Islam (Jakarta: Kalam Mulia, 2015).
} 


\section{The Reality of Learning and Capacity-Based Fulfillment at Darul Ma'arif Islamic Boarding School in Jayapura}

success of implementation requires the realization of activities. The various realities of learning capacity-based Islamic boarding schools in Jayapura can be seen as follows.

\section{Implementation of Learning at the Darul Ma'arif Islamic Boarding School}

Each institution of any kind has a variety of plans activities that seek to be realized, would be but sometimes are not able to plan these activities as a whole to be realized. The success of a plan must go through a stage called implementation. Through these stages of implementation, it can be seen whether the implementation is by the plan. Likewise, the Darul Maarif Islamic Boarding School in Jayapura which has various programs planned to be implemented every year.

The implementation of learning at the Darul Maarif message boarding school was revealed by informant Salman, who is the representative of the Darul Ma'arif Islamic Boarding School, who said that the Yellow Book learning was constrained by the non-permanent teaching staff in teaching the boarding materials and among the materials. Pondok that is taught, read alQur'an, Bulugul maram, khat/Imla, safinatunnajah, arbain Nawawi, jawahirul kalamiyah, ta'limul mutaallim. ${ }^{12}$

The explanation above explains that learning pondok with existing materials includes reading al-Quran, Bulugul maram, khat/Imla, safinatunnajah, and arbain Nawawi, ta'limul mutaallim, jawahirul kalamiyah, is constrained by a lack of teaching staff so that teaching only general with the lecture method, and also the condition of the santri, most of whom did not live in the hut.

Although the materials have been arranged well with the time of day starting after Fajr, Asr and after sunset and evening, in fact learning only takes place in general with the lecture method. So that the level of success in learning the Darul Maarif Islamic Boarding School in Jayapura is said to be unsatisfactory. If the success is satisfactory, then there will be no more Islamic boarding schools, especially Darul Ma'arif. There will be no shortage of teaching staff, especially those who teach pondok materials, because these materials should have been well received by the students, which can then be transferred to new students as to how. That goes on in the big lodges there.

\section{Learning Methods at the Darul Ma'arif Islamic Boarding School in Jayapura}

Any work should be done with the right method to get good results, as well as in the case of learning carried out in an educational institution. Without the right method, it is difficult to achieve learning objectives. The learning method is not only necessary and carried out by the public schools, would be but also very necessary for the boarding school in the implementation of learning.

The method commonly used in Islamic boarding schools includes the Sorogan method, which means individual learning in which a student faces a teacher, there is mutual interaction between the two. Another method, namely Bandongan, means learning in groups which are followed by all students, while Halaqah is a discussion to understand the book, not to ask the possibility of right and wrong things taught by the book, but to understand what the book teaches.

\footnotetext{
${ }^{12}$ Salman, "Leader of the Darul Ma’arif Numbay Islamic Boarding School” (Jayapura, 2019).
} 
Bandongan method or often called weton. In this system a group of students (between 5 and 500 students) listens to a teacher who reads, translates, explains, and even occasionally reviews Islamic books in high-level Arabic given to senior students, each student listens and makes notes about the words-difficult word. System class group bandongan is called halaqah the meaning of the language is a circle of students or groups of students who studied under the guidance of a teacher. While the sorogan system is the most difficult system of the entire pesantren education system because this method requires patience, diligence, obedience, and discipline for a teacher. This method is for new students who still need individual guidance.

The application of the method in learning according to the context of the Jayapura Darul Ma'arif Islamic Boarding School as mentioned above has not been realized, and to find out about the teaching method of the Darul Maarif Islamic boarding school in Jayapura, here are the results of an interview with informant Shabur who is a teacher at the Darul Ma'arif Islamic Boarding School. The city of Jayapura who said that the implementation of the pondok program, especially book learning, used the bandongan method, and not all students took part in this program, because this program was only intended for those who had passed basic programs both reading and writing the Quran, nahwu and sharaf, because there are also students who have not been able to read the Quran, let alone master nahwu and sharaf, so the lodge held a preparatory program, namely the reading and writing program of the Quran and nahwu sharfu. ${ }^{13}$

Through the explanation above, it is known that the Darul Ma'arif Islamic boarding school uses the bandongan method, its implementation is not like what has been going on so far in various salafi/traditional pesantren which teach as the real bandongan method, because learning is only general with the lecture method. And also the bandongan method will have an impact if previously applied the sorogan method with the right materials, because the basis for better understanding the material using the bandongan method requires basic material with the sorogan method, and this is not the case at the Darul Maarif Islamic Boarding School in Jayapura. So that what happens the results obtained are very far from expectations.

3. The Success Rate of Learning Implementation at Darul Ma'arif Islamic Boarding School

Each learning that is carried out can be measured the level of success if the stages of management can be passed properly. Where the success of the implementation of learning can be seen from the program evaluation and improvement of the evaluation, namely by making improvements to the implementation of the same learning in the following activities carried out. Likewise, the level of success in the implementation of the Darul Maarif Islamic Boarding School learning implementation, it can be done by evaluating the implementation of learning.

The success rate of implementing the Darul Maarif Islamic Boarding School program in Jayapura, along with the explanation of informant Salman, who is the leader of the Darul Ma'arif Abepura Islamic Boarding School, Jayapura, said that the

${ }^{13}$ Abd. Shabur, "Coordinator of Takhassus Pondok Pesantren Darul Ma'arif Numbay" (Jayapura, 2019). 
success of students, especially in boarding learning, was not satisfactory, this was due to the learning of the boarding school even though a schedule and materials have been arranged, but the lecture is only general, and there is no final evaluation of the materials presented in the evening recitation program, after dawn, dusk and evening. ${ }^{14}$

The explanation above explains the absence of consistency in the application of Islamic boarding school learning both in terms of student discipline, as well as materials as material for ustadz to teach. From the materials presented, the number of teaching hours, teaching methods are all left to the cleric concerned, plus there is no evaluation in every book taught.

The success of learning at the pesantren is determined by the appearance of the ability to teach books to others, in this case, the seniors to the juniors. If the audience is satisfied, then it means that the student in question has passed the lesson. This is due to the absence of an evaluation of the learning success of the students to be able to move to study other books of a higher level and to teach books that have been mastered to others or their junior students. For this reason, various evaluations are needed on the implementation of Islamic boarding school learning, to carry out evaluations in the form of changes precisely and carefully so that the success rate of implementing Islamic boarding school learning in Darul Ma'arif Islamic Boarding School can run effectively and efficiently.

\section{B. Fulfilling the Capacity of the Darul Ma'arif Islamic Boarding School in Jayapura}

The progress of educational institutions at the primary, secondary and upper levels, even higher education institutions, is strongly influenced by the availability of supporting success in the form of facilities and infrastructure, as well as other supporting facilities that are very supportive in the context of the progress of the education institutions.

Like the presence of students or the existence of professional teachers who are needed by these educational institutions to support the achievement of their goals. Likewise, with boarding school-based education, which is rife by Muslims in Indonesia, wherein its development, it is necessary to have Kiai, student, and adequate facilities and infrastructure, to support the realization of the goals they want to achieve from the implementation of education to be able to continue to exist in its implementation.

1. Aspects of Kiai (Competencies and qualifications of Kiai) in Darul Ma'arif Islamic Boarding School, Jayapura

The existence of a kiai as a leader and at the same time as owner of a boarding school his duties and functions are required to have broad wisdom and insight, be skilled in religious sciences, be able to instill attitudes and views, and must be a role model for Kiai in his duties and functions. The phenomenon of supernatural power, where the Kiai figure as a scholar is considered the heir to the prophetic treatise. So that the existence of Kiai is almost associated with someone who has a relationship with Allah.

${ }^{14}$ Salman, "Leader of the Darul Ma'arif Numbay Islamic Boarding School." 
Although in general the existence of Kiai is only seen as an informal leader, Kiai is believed to have superiority, both morally and as a religious person. Kiai's influence was taken into account both by national officials and by the general public. However, in reality, there does not appear to be a Kiai aspect of implementing Islamic boarding schools in Jayapura. To find out about the above, it can be seen as expressed by Salman, who is the head of the Jayapura Islamic boarding school Daarul Ma'arif Abepura, who said that the history of the establishment of the cottage cannot be seen by one of the six founders who are more dominant with each other in terms of knowledge. Religion, charisma, and educational qualifications, so that they can be called Kiai, even if there are only limited to the title teacher or ustadz which does not describe the figure of the Kiai depicted.

As for the teaching staff, it is still very lacking, when compared to the teaching staff who teach the Ministry of Religion Curriculum, so the Darul Ma'arif Islamic boarding school brings ustadz to specifically teach the yellow book. However, what is an obstacle is that there are still teachers/ustadz who are honorary so that he is very less attached to the institution, where he can leave the Pondok at any time. ${ }^{15}$

The explanation that has been described above can be conveyed that the process of establishing the Darul Ma'arif Islamic boarding school in Jayapura does not originate from Kiai figures, who are characterized as leaders and at the same time as owners of an Islamic boarding school in their duties and functions which are intended to have broad, skilled wisdom and insight. in the religious sciences, being able to instill attitudes and views, and being a role model for a Kiai in their duties and functions are often associated with the phenomenon of supernatural power, where the Kiai figure as a scholar is considered the heir of a prophetic treatise.

The existence of a Kiai is seen as important as a figure who has a relationship with Allah, but his stance came from several ustadz or teachers who took the initiative to establish an Islamic education institution which has an important role so that the selection of students to a pesantren institution occurs due to the quality of the pesantren guidance system, organizational ties or family relations, not because of the fame and charismatic of a Kiai as is the case in other areas in Indonesia, also where the establishment of the Darul Ma'arif Islamic boarding school was not driven by a person, but by several people, as well as one's domination of the progress and retreat of the boarding school. It appears, so it can be said that the Kiai figure does not exist in the Darul Ma'arif Islamic boarding school in Jayapura, but what does exist is a boarding school leader who has some expertise in the field of religion and is an alumnus of the Islamic boarding school with an undergraduate educational qualification level.

On this basic, it can be stated that Kiai aspect in the Darul Ma'arif Islamic boarding school is not an important aspect in the establishment and development of the Islamic boarding school, where the Darul Maarif Islamic boarding school does not yet have a charismatic Kiai figure, who has qualified material and spiritual strength so that it is capable of to be a figure for every student, even everyone in the hut.

Thus what Darul Ma'arif Islamic boarding school needs is a professional leader in a charismatic field who can be used as a role model both in terms of science and role model depicted by the figure of a Kiai, to be able to produce quality graduates.

\footnotetext{
${ }^{15}$ Salman.
} 


\section{The Reality of Learning and Capacity-Based Fulfillment at Darul Ma'arif Islamic Boarding School in Jayapura}

Besides, it is hoped that the boarding school will increase the number of permanent teachers/clerics, so that they can transfer their knowledge as much as possible. Where when more clerics who teach are honorary chaplains, it will interfere with the implementation of education at the Islamic boarding school, which at any time the ustadz can leave the boarding school, this is because there is no clear bond between the honorary ustadz and the pesantren concerned.

So that this can affect the knowledge of the student where the knowledge of the student can be interrupted when the ustadz concerned is no longer teaching at the pesantren.

2. Santri Aspects (Input and Output) in the Darul Ma'arif Islamic Boarding School , Jayapura

The term santri or student is only found in Islamic boarding school education, where santri are students and are young cadres who study religious knowledge more deeply in pondok, where usually students study classical books that are not taught in public schools. Like public schools that need students so that the teaching and learning process occurs, Islamic boarding school education also really needs the presence of students, so that the teaching and learning process is created, so that it can carry out the transfer of knowledge from ustadz to its students, where without the presence of students the boarding school will not be able to established and running optimally. Likewise, what happened to the Darul Ma'arif Islamic boarding school in Jayapura, where Islam is the second religion in terms of the number of its adherents in the City of Jayapura, making it possible to obtain santri for the Darul Ma'arif Islamic boarding school, where without students the Islamic boarding school will not be able to stand up and carry out the learning.

Regarding the santri aspect related to the input and output of the santri at the Darul Ma'arif Islamic boarding school in Jayapura, the informant Salman, who is the Deputy Head of the Darul Ma'arif Islamic Boarding School in Jayapura, said that the Darul Ma'arif Islamic Boarding School is an Oldest Islamic boarding school in Jayapura, most of the people of Jayapura have recognized pondok as free cottage without charge, but what happens is that the need for pondok is very large to finance any existing programs and teachers, so when there is a free application for the cottage, what happens There is a decrease in the number of incoming santri, there are now 500 students consisting of Raudhatul Atfal, madrasah ibtidaiyyah, madrasah tsanawiyah and madrasah aliyah, but of the number of existing students, only about 100 students live in the pondok, this is also a problem implementation of cottage programs. ${ }^{16}$

The explanation above illustrates that the number of students is less than 500 which is a classification of lodges that are classified as small, especially not supported by strict regulations on santri who have to live in the hut, because of the five hundred students and female students, only about $10 \%$ are students. who live in the Darul Maarif Islamic boarding school, and most of them are students who can return home at any time. The Darul Ma'arif Islamic boarding school, which is classified as a combination, is in demand by santri whose parents work as civil servants, traders, laborers and farmers. Santri can move from one pesantren to another. After completing

\footnotetext{
${ }^{16}$ Salman.
} 
a book and will continue to another pesantren to explore other books which are the expertise of a Kiai.

In the salaf pesantren, the length of time the students stay in the boarding school is not determined by the size of the year or class, but is measured by the books that have been read and memorized. The higher the book, the more difficult it is to understand its contents. So before mastering high books, you should master books that are classified as basic. In the context of the Darul Ma'arif Islamic boarding school in Jayapura, the pattern of the santri moving from one pesantren to another is not applied.

Besides, each pesantren prefers formal education and there is also no charismatic Kiai with the scientific deepening of certain books, as revealed from the results of an interview that the Darul Maarif Islamic boarding school in Jayapura organizes pesantren education, with the madrasah system.

This tendency is due to the guidance of the parents of students who want their children to have a formal certificate which can later be used to continue their education or apply for jobs. However, what happened was that the students continued to go to public schools after completing their education at the Islamic boarding school at one level of education. The dominant students entered the pesantren at the madrasah tsanawiyah level and continued their education at the madrasah aliyah in the pesantren. However, there are also students after continuing their education in public schools after completing their education at madrasah tsanawiyah in Islamic boarding schools. $^{17}$

In this connection, it can be said that the existence of santri is an important aspect in any Islamic boarding school, including the Hidayatullah Islamic Boarding School in Jayapura, where without the presence of students it is difficult to develop a boarding school. However, the right strategy is needed in attracting students, so that a boarding school will continue to exist in its development.

For example, in terms of good management of the boarding school starting from facilities and infrastructure, professional teachers, to more relevant Islamic boarding school programs, namely those who can produce quality graduates who can continue the development of Islamic education in the community, especially in Jayapura and Papua in general.

3. Aspects of Facilities and Infrastructure/Pondok and Dormitory (Fulfillment of Supporting Elements) Darul Ma'arif Islamic Boarding School, Jayapura

A supporting factor that is sometimes overlooked by an educational institution is the availability of adequate facilities and infrastructure, where adequate facilities and infrastructure are an attraction that educational institutions have in addition to being able to support the learning process it is also able to generate perceptions about the educational institution in the eyes of the community. With adequate facilities and infrastructure, it is hoped that it will be able to attract the desire of the community to be able to study at these institutions.

Likewise with Islamic boarding schools, where the availability of facilities and infrastructure is needed to complete the educational institution so that it can be said to

\footnotetext{
${ }^{17}$ Salman.
} 


\section{The Reality of Learning and Capacity-Based Fulfillment at Darul Ma'arif Islamic Boarding School in Jayapura}

be feasible as an educational institution. Likewise with the existence of the Darul Ma'arif Islamic boarding school, where adequate facilities and infrastructure are needed to be able to develop boarding school-based education in Jayapura. This is to find out about the availability of facilities and infrastructure in the Darul Ma'arif Islamic boarding school in Jayapura.

The following is an excerpt from an interview with the head of the Darul Ma'arif Abepura Islamic boarding school, Jayapura, who said that the existence of male and female dormitories is permanent with a capacity of 70 for santri and 50 for santriwati, because most of the students live in outside the hut. Likewise, with the mosque which can accommodate 1000 students, leadership and teacher rooms, adequate fields and cooperatives, language laboratories and libraries, all facilities are permanent, but the references owned by the library are very lacking. and teachers/ustadz who teach cottage materials. ${ }^{18}$

The explanation above explains that the availability of facilities is quite adequate in the presence of adequate male and female dormitories. Mosque accommodates 1000 male and female students, the teacher's lounge, classroom, laboratory languages and libraries, cooperative, decent pitch, it's just a shortage of reference in terms of materials cottage.

For Darul Ma'arif Islamic boarding school, the shortage of teachers/ustadz is a major factor in the success of boarding school education because teachers are the main factor in the implementation of education, especially religious education, but what happens to Darul Ma'arif Islamic boarding school is the teacher who is the source of the problem of educational activities in the boarding school. Darul Ma'arif Islamic boarding school.

The construction of various facilities needs to be improved to develop the Darul Ma'arif Islamic boarding school, namely various creative business means to be able to develop the knowledge of santri in entrepreneurship, as well as can increase the funding sources for the boarding school, so that deficiencies become a problem in the development of the Darul Maarif Islamic boarding school can be resolved properly.

\section{Curriculum Aspects (Content and Quality of Curriculum)} in Darul Ma'arif Islamic Boarding School, Jayapura

The content and quality of the curriculum in an educational institution greatly influences the results of the graduates of that educational institution, which are expected to be able to compete with other educational institutions that have the same competence. Where it is hoped that educational institutions will be able to organize the curriculum properly so that the content and quality of the curriculum to answer the challenges of the times, where science is increasingly developing so that every educational institution is required to develop and not stagnate in responding to the challenges of the outside world. Likewise, the existence of Darul Ma'arif Islamic boarding school education, where the results of its graduates are expected to be able to compete with graduates of other Islamic boarding schools outside Jayapura in terms of mastery of religious learning material.

Regarding the Curriculum um (charge and the quality of the curriculum) boarding school Darul Ma'arif city of Jayapura, it can be seen from the

\footnotetext{
${ }^{18}$ Salman.
} 
narrative Shobur which is a cottage teacher Darul Ma'arif, that the curriculum used by the boarding school Darul Ma'arif using a curriculum that is set by the Indonesian Ministry of Religion. Meanwhile, Islamic Religious Education in more depth is given to students in non-formal education or in other terms takhassus which is held after each obligatory prayer, except the midday prayer. The procedures for non-formal Islamic education are mostly in the form of yellow book studies. Non-formal education or takhassus must be followed by students at the MTs and MA levels. Non-formal education starts after Fajr prayer until 6:00 a.m. Furthermore, after the Asr prayer until 17.00. After maghrib prayer, non-formal education is continued until it is time for the evening prayer. After the evening prayer and dinner, the students returned to attend takhassus until 21.30 or 20.00 . Then return to their respective dormitories and rest. $^{19}$

As stated, the takhassus program in this case the pondok programs are only specifically for sanrti and santriwati tsanawiyah and aliyah who are more specialized in learning the yellow book, but the application of the learning is still general and not focused on the control of the center towards mastery of the yellow book, this it can be seen from the absence of book study standards, both at the middle and upper levels. The presentation of material that is only general, and does not direct the santri in the mastery of reading books, let alone in understanding them.

Santri Darul Ma'arif is not only students of Madrasah Tsanawiyah and Aliyah, but also Raudhatul athfal and Madrasah Ibtidaiyyah who must also be considered, because they should not go to Darul Ma'arif Islamic boarding school, but they are still learning to read the Koran other madrasas, because pondok only focuses on takhassus for santri and santriwati at Madrasah Tsanawiyah and Aliyah, as has happened in other Islamic education institutions in Jayapura.

This is done so that in the future santri who are graduates of Islamic boarding schools can continue to various existing schools, both religion-based and public schools and are expected to be able to adapt and compete with existing public schools.

It should be hoped that the Darul Maarif Islamic Boarding School in Jayapura will be able to balance the curriculum of the Ministry of Religion of the Republic of Indonesia and the Islamic Boarding School curriculum so that one of them is not impressed that one of them is more dominant in the implementation of learning at Islamic boarding schools in Jayapura, so that what students receive is a blend of knowledge. which is expected, namely being able to add/improve knowledge and be able to compete in terms of religious and general sciences with other educational institutions.

\section{REFERENCE}

Azra, Azyumardi. Jaringan Ulama Timur Tengah Dan Kepulauan Nusantara Abad XVII \& XVIII. Jakarta: Kencana Predana Media Group, 2004.

Barnadib, Imam. Ke Arah Perspektif Baru Pendidikan. Yogyakarta: FIP-IKIP, 1994.

\footnotetext{
${ }^{19}$ Shabur, "Coordinator of Takhassus Pondok Pesantren Darul Ma'arif Numbay."
} 
Damopolii, Muljono. Pesantren IMMIM Pencetak Muslim Modern. Jakarta: Rajawali Pers, 2011.

Daulay, Haedar Putra. Pendidikan Islam Dalam Sistem Pendidikan Nasional Di Indonesia. Jakarta: Premanadamedia Group, 2014.

Idham. Potret Pemberdayaan Santri; Pesantren Dan Studi Islam. Jakarta: Panrita Global Media, 2010.

Lubis, Saiful Akhyar. Konseling Islam Kyai Dan Pesantren. Yogyakarta: Elsaq Presss, 2007.

Madjid, Nurcholish. Bilik-Bilik Pesantren. Jakarta: Dian Rakyat, 2010.

Qomar, Mujammil. Pesantren Dari Transformasi Metodologi Menuju Demokratisasi Institusi. Jakarta: Erlangga, 2002.

Ramayulis. Ilmu Pendidikan Islam. Jakarta: Kalam Mulia, 2015.

Salman. "Leader of the Darul Ma'arif Numbay Islamic Boarding School." Jayapura, 2019.

Shabur, Abd. "Coordinator of Takhassus Pondok Pesantren Darul Ma'arif Numbay." Jayapura, 2019.

Tafsir, Ahmad. Ilmu Pendidikan Islam. Bandung: Remaja Rosda Karya, 2013. 